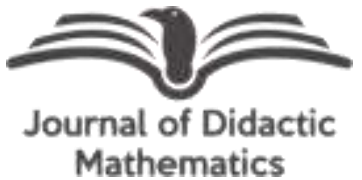

\title{
Penerapan model pembelajaran kooperatif tipe jigsaw untuk meningkatkan kemampuan pemahaman konsep siswa pada pokok bahasan kubus dan balok di kelas VIII SMP Bhayangkari Medan
}

\author{
Nurmala Hayati* \\ Universitas Negeri Medan, Medan, Sumatera Utara, Indonesia, 20221 \\ *Corresponding Author: nurnalahayati@gmail.com
}

\begin{abstract}
This research is in the form of Classroom Action Research (CAR). The subjects in this study were students of class VIII-I of Bhayangkari Medan Middle School and the number of subjects in this class were 40 students. The instrument used to measure students' concept comprehension ability was in the form of filling, with validation and reliability coefficients of the instrument (0.852) for concept comprehension abilities, then the instruments used were observation sheets. The results of the study in the first cycle were obtained as follows: (1) the average understanding of the concept of students 63.90 , (2) the percentage of teacher mastery in learning was only $67.85 \%$ and (3) students who achieved completeness were only $56.25 \%$. Then proceed to the second cycle, so the results obtained in the second cycle are as follows: (1) the average ability of students' understanding of concepts is achieved as expected by 79.4, (2) the percentage of teacher mastery is also in accordance with the target of 89.75 and (3) the percentage of students completeness was $83.75 \%$. Based on the results of the second cycle each aspect has met the minimum completeness criteria so that research is not continued in the next cycle.
\end{abstract}

Historis Artikel:

Diterima: 25 Februari 2020

Direvisi: 3 Maret 2020

Disetujui: 27 Maret 2020

\section{Keywords:}

Cooperative Jigsaw, understanding concepts, cubes and beams

Sitasi: Hayati, N. (2020). Penerapan model pembelajaran kooperatif tipe jigsaw untuk meningkatkan kemampuan pemahaman konsep siswa pada pokok bahasan kubus dan balok di kelas VIII SMP Bhayangkari Medan. Journal of Didactic Mathematics, 1(1), 1-7. https://doi.org/10.34007/jdm.v1i1.145

\section{PENDAHULUAN}

Dalam menghadapi era globalisasi yang penuh tantangan, pendidikan merupakan aspek yang sangat penting karena dengan pendidikan diharapkan mampu membentuk sumber daya manusia yang terampil, kreatif dan inovatif. Untuk membentuk sumber daya manusia sesuai dengan perkembangan zaman diperlukan penguasaan ilmu pengetahuan dan teknologi. Pendidikan menekankan pada proses belajar yang bertujuan untuk mengembangkan seluruh potensi yang ada pada diri manusia baik aspek kognitif, afektif maupun psikomotorik. Pendidikan formal yang dilakukan di sekolah sampai sekarang tetap merupakan lembaga pendidikan utama yang merupakan pusat pengembangan sumber daya manusia dengan didukung oleh pendidikan dalam keluarga dan masyarakat.

Matematika sebagai salah satu sarana berpikir ilmiah adalah sangat diperlukan untuk menumbuhkembangkan kemampuan berpikir logis, sistematis, dan kritis dalam diri peserta didik. Demikian pula matematika merupakan pengetahuan dasar yang diperlukan oleh peserta didik untuk menunjang keberhasilan belajarnya dalam menempuh pendidikan yang lebih tinggi. Bahkan matematika diperlukan oleh semua orang dalam kehidupan sehari-hari. Karena itulah, peserta didik perlu memiliki pengetahuan matematika yang cukup untuk menghadapi masa depan.

Menyadari akan pentingnya peranan matematika, baik dalam penataan nalar dan pembentukan sikap maupun dalam penggunaan matematika, maka peningkatan hasil belajar matematika di setiap jenjang pendidikan perlu mendapat perhatian yang sungguh-sungguh. Guru hendaknya dapat menyusun program pengajaran yang dapat membangkitkan hasil belajar siswa 
sehingga siswa terlibat secara aktif dalam proses belajar mengajar. Dengan demikian penghayatan terhadap matematika akan lebih mantap dan dapat menghilangkan anggapan siswa bahwa pelajaran matematika adalah pelajaran yang sulit.

Salah satu penyebab prestasi matematika siswa masih rendah adalah kurangnya pemahaman siswa terhadap konsep-konsep yang terdapat dalam matematika dan masih sulitnya siswa berkomunikasi secara matematik. Hal ini dikarenakan guru pada waktu mengajar belum menggunakan metode pembelajaran yang dapat mendorong siswa berpikir dan melibatkan siswa secara aktif. Masih banyak guru dalam mengajar menggunakan metode pembelajaran secara konvensional.

Dalam metode ini lebih banyak menuntut keaktifan guru daripada siswa sebagai peserta didik sehingga siswa kurang aktif dalam proses belajar mengajar. Hal ini dapat mengakibatkan pencapaian tujuan pembelajaran oleh para siswa tidak optimal. Pembelajaran yang seperti ini juga tidak memberikan kebebasan berpikir para siswa, serta tidak merangsang keterampilan dan kreativitas siswa, melainkan belajar hanya untuk tujuan singkat. Pembelajaran yang seperti ini akan sangat merugikan siswa dan akan membunuh kreativitas siswa dalam memecahkan masalah dan siswa akan mengalami kesulitan dalam pemahaman konsep matematika. Keadaan seperti ini akan dapat menurunkan tingkat pemahaman siswa dalam memahami konsep matematika.

Kubus dan Balok merupakan materi pelajaran di kelas VIII SMP semester genap. Prasyarat yang diperlukan untuk mempelajari materi ini adalah materi persegi dan persegi panjang. Adapun sub pokok bahasan yang dipelajari pada materi kubus dan balok yaitu: (1) mengenal kubus dan balok, (2) unsur-unsur pada kubus dan balok, (3) menggambar kubus dan balok, (4) jaring-jaring kubus dan balok, (5) luas permukaan kubus dan balok, (6) volume kubus dan balok, (7) perubahan kubus dan balok, dan (8) penerapan kubus dan balok.

Materi ini bukan materi yang baru lagi bagi siswa karena sudah pernah mereka pelajari di tingkat SD. Akan tetapi masih banyak siswa yang mengalami kesulitan dalam mempelajari, mengenal dan menyelesaikan soal-soal kubus dan balok. Metode yang digunakan pada kubus dan balok ini pada umumnya metode ceramah. Pengajaran berpusat kepada guru bukan kepada siswa, sehingga mengakibatkan peran siswa sangat minim. Guru masih bersifat aktif sebaliknya jika siswa dilibatkan lebih aktif maka siswa akan lebih berpotensi mengeluarkan semua kemampuan yang ada dalam dirinya secara positif dan mengkonstruksikan ide-idenya. Tetapi dalam kegiatan ini pembelajaran siswa kurang aktif dan siswa lebih banyak mendengar saja tanpa mengeluarkan gagasan/ide-ide mereka sendiri. Dari hasil tes diagnostik pada pokok bahasan kubus dan balok diperoleh informasi bahwa tingkat kreativitas siswa termasuk kategori rendah. Dari 27 orang siswa yang mengikuti tes tidak ada siswa yang bernilai lebih besar dari 70, semua siswa bernilai kurang dari atau sama dengan 50 .

Rendahnya pemahaman konsep dan kreativitas siswa lebih terlihat khusus pada pokok bahasan kubus dan balok yang bersifat abstrak sehingga memerlukan visualisasi atau model pembelajaran yang relevan. Sehubungan dengan hal itu perlu adanya suatu model pemebalajaran yang dapat meningkatkan pemahaman dan kreativitas siswa dalam suatu permasalahan matematika. Penggunaan model pembelajaran kooperatif tipe jigsaw merupakan salah satu alternatif lain untuk dapat meningkatkan pemahaman konsep dan kreativitas siswa.

Model pembelajaran kooperatif tipe Jigsaw ini melibatkan siswa untuk berperan aktif untuk berdiskusi dalam kelompok dan bertanggung jawab atas penguasaan materi yang dipelajari bukan hanya untuk diri sendiri tetapi juga untuk anggotanya.

\section{METODE}

Jenis penelitian ini adalah penelitian tindakan kelas (classroom action research) yaitu penelitian tindakan (action research) yang dilakukan dengan tujuan memperbaiki mutu praktik pembelajaran di kelas. Karena penelitian ini bertujuan untuk mengungkap kendala dan kesulitan yang dialami siswa dalam menyelesaikan permasalahan Kubus dan Balok dan menjelaskan upaya-upaya yang 
Penerapan model pembelajaran kooperatif tipe jigsaw untuk meningkatkan kemampuan...

dilakukan untuk meningkatkan pemahaman konsep dan kreativitas siswa dalam memecahkan masalah matematika pada materi Kubus dan Balok.

Lokasi dilakukannya penelitian ini adalah di SMP Bhayangkari Medan, kelas VIII dan pelaksanaannya pada semester genap, Tahun Pelajaran 2013/2014, Sedangkan instrument yang digunakan adalah tes dan observasi. Kemudian untuk teknik analysis data menggunakan reduksi data.

\section{HASIL DAN PEMBAHASAN}

Deskripsi Hasil Tes Awal

Berdasarkan hasil observasi terdahulu yang dilakukan peneliti ke sekolah SMP Bhayangkari Medan diperoleh bahwa kemampuan Pemahaman konsep dan kemampuan kreativitas masih rendah.

Subjek dalam penelitian ini adalah kelas VIII-1 SMP Bhayangkari Medan yang berjumlah 40 siswa. Sebelum melaksanakan siklus I, peneliti terlebih dahulu memberikan tes awal kepada siswa sebagai rujukan gambaran kemampuan seberapa besar kemampuan pemahaman konsep dan kemampuan kreativitas siswa serta pembagian kelompok diskusi siswa sebagai kriteria dalam melaksanakan pembelajaran kooperatif tipe jigsaw. Tes awal ini terdiri dari dua soal dimana satu soal untuk mengukur pemahaman konsep siswa dengan topik kubus dan balok yang pernah dipelajari sebelumnya.

Tabel 1. Deskripsi Tingkat Kemampuan Pemahaman Konsep pada Tes Awal

\begin{tabular}{cccc}
\hline Skala Nilai & Kriteria Nilai & Banyak Siswa & Persentase jumlah Siswa \\
\hline $85 \%-100 \%$ & Sangat Baik & 0 & $0 \%$ \\
\hline $70 \%-84 \%$ & Baik & 1 & $3 \%$ \\
\hline $55 \%-69 \%$ & Cukup Baik & 1 & $3 \%$ \\
\hline $40 \%-54 \%$ & Kurang baik & 12 & $35 \%$ \\
\hline $0 \%-39 \%$ & Sangat Kurang Baik & 20 & $59 \%$ \\
\hline & Jumlah & 34 & $100 \%$ \\
\hline
\end{tabular}

Keterangan: Jumlah siswa 40 orang dan 6 orang tidak hadir mengikuti tes

\section{Deskripsi Hasil Penelitian Siklus I}

Berangkat dari tes awal yang dilakukan pada kelas VIII-I terdapat kelemahan-kelemahan pemahaman konsep siswa untuk itu dilakukan penelitian tindakan kelas. Oleh karena itu untuk menyelesaikan masalah-masalah yang dihadapai siswa dilakukan penelitian tindakan dimulai dari siklus I.

\section{Permasalahan}

Berdasarkan hasil tes awal, dapat diperoleh letak kesulitan siswa dalam menyelesaikan soal; (1) siswa masih kurang mampu menuliskan informasi dengan tepat. Kebanyakan siswa masih menuliskan seluruh isi soal yang diberikan pada siswa. Hal ini dikarenakan siswa belum mampu mengerti apa yang dimaksud dari dari soal; (2) siswa masih belum dapat mempresentasikan soal cerita yang diberikan lalu memodelkan dalam bentuk matematika; (3) konsep yang digunakan dalam menyelesaikan masalah/soal masih belum tepat; (4) idenya dalam menyelesaikan masalah yang diberikan masih monoton; (5) kurang mengembangkan idenya dalam menyelesaikan masalah.

\section{Rencana Tindakan}

Untuk mengatasi rendahnya kemampuan Pemahaman konsep direncanakan pembelajaran dengan menerapkan model pembelajaran kooperatif tipe jigsaw. Tindakan yang akan diambil adalah; (1) menyusun rencana pelaksanaan pembelajaran (RPP) yang berisikan langkah-langkah kegiatan 
dalam pembelajaran yang menggunakan model pembelajaran kooperatif tipe jigsaw; (2) mempersiapkan sarana pendukung pembelajaran yang mendukung pelaksanaan tindakan; (3) mempersiapkan instrumen penelitian; (4) menyiapkan instrumen yang lebih menarik untuk mereka pecahkan dan kalimatnya yang digunakan tidak terlalu kaku, disesuai dengan usia mereka dan katakata yang mereka gunakan.

\section{Pelaksanaan Tindakan}

Pelaksanaan tindakan I terdiri dari dua pertemuan untuk melaksanakan kegiatan pembelajaran sesuai RPP yang telah disusun dan satu pertemuan untuk melakukan tes kemampuan pemahaman konsep siswa. Pelaksanaan tindakan I tersusun atas; (1) memberikan apersepsi kepada siswa dengan menyampaikan tujuan pembelajaran yang akan dicapai tiap pertemuan untuk membangkitkan motivasi belajar mereka; (2) menyajikan informasi kepada siswa dengan bantuan menjukkan media pembelajaran berupa gambar kubus dan balok yang sudah dipersiapkan sebelumnya; (3) guru membimbing siswa memahami materi ajar melalui tanya jawab mengenai materi kubus dan balok serta menggambarkannya di papan tulis dalam ukuran besar dan jelas bentuk dari komponenkomponen dari kubus dan balok; (4) guru memberikan contoh latihan soal cerita kemudian membimbing siswa menyelesaikannya; (5) guru membentuk kelompok diskusi; (6) memberikan soal cerita yang disajikan dalam LAS yang telah disiapkan kemudian menyuruh siswa untuk menunjukkan jawaban mereka masing-masing jika jawaban mereka berbeda-beda baik salah ataupun benar dan cara yang beragam untuk memperoleh jawaban mereka.

\section{Pengamatan}

Berdasarkan hasil observasi siklus I, diperoleh kemampuan guru dalam mengelolah pembelajaran pada pertemuan I, diperoleh kemampuan guru dalam mengelolah pembelajaran pada pertemuan I sebesar 60,7\% dengan nilai rata-rata 2,43 dan masih digolongkan dalam kategori cukup baik, sedangkan pada pertemuan II diperoleh kemampuan guru dalam mengelolah pembelajaran mengalami kemajuan menjadi sebesar 75,0\% dengan nilai akhir 3,00 dan digolongkan ke dalan kategori baik. Sehingga pertemuan II lebih baik penguasaan kelasnya jika dibandingkan dengan pertemuan pertama. Akan tetapi, guru masih kurang maksimal dalam mengefektifkan kondisi kelas saat kegiatan berdiskusi. Pada saat siswa membacakan masalah yang terdapat dalam LAS, guru (peneliti) masih belum maksimal dalam mengatur kondisi kelas sehingga tidak terkesan gaduh. Selain itu, masih ada dijumpai kelompok yang pasif. Bahkan ada juga dijumpai kelompok yang masih belum tepat melakukan kegiatan diskusi sesuai dengan model pembelajaran kooperatif jigsaw.

\section{Deskripsi Tes Kemampuan Pemahaman Konsep I}

Berdasarkan hasil tes kemampuan pemahaman konsep matematika pada siklus I, pada tes bagian pertama ini terdapat satu siswa tidak hadir karena sakit sehingga jumlah siswa pada saat dilakukan evaluasi berjumlah 39 siswa yang seharusnya 40 siswa. Hasil kemampuan pemahaman konsep matematika siswa pada siklus pertama cukup memuaskan tetapi masih ada 12 siswa atau sekitar $30 \%$ yang nilainya masih rendah. Pada hasil tes siklus I, terdapat 6 siswa (15\%) yang mendapat kategori sangat baik, 11 siswa (28\%) yang mendapat kategori baik, 10 siswa $(26 \%)$ yang mendapat kategori cukup baik, 8 siswa (21\%) yang mendapat kategori kurang baik dan 4 siswa (10\%) yang masuk kategori sangat kurang baik.

\section{Deskripsi Hasil Penelitian Siklus II}

Bertolak dari hasil penelitian yang diperoleh pada siklus I, terdapat kelemahan-kelemahan baik dari faktor aktivitas guru maupun kemampuan yang akan dicapai siswa yaitu pemahaman konsep siswa serta ketuntasan belajar siswa belum tercapai. Oleh karena itu dilkukan siklus II, yang terdiri dari empat tahap permasalahan, rencana, pelaksaan dan refleksi. 
Penerapan model pembelajaran kooperatif tipe jigsaw untuk meningkatkan kemampuan...

Permasalahan

Berdasarkan analisis data pada siklus I terhadap 39 siswa diperoleh terdapat masih 17 orang (43 $\%$ ) yang berkategori baik dan sangat baik. Sementara itu rata-rata kemampuan pemahaman konsep meningkat sebesar 85,6\% dari 34,4 pada tes awal menjadi 63,9. Maka, yang menjadi masalah yang akan diatasi pada siklus ini adalah; (1) rata-rata kemampuan pemahaman konsep 69,5 masih dikategorikan cukup baik; (2) jumlah siswa yang berkategori baik atau sangat baik adalah 17 siswa $(43 \%)$ dari seluruh siswa dan jumlahnya masih belum mencapai standar yaitu sebesar $85 \%$ dari jumlah siswa dalam kelas; (3) siswa masih belum mampu mempresentasikan bentuk jaring-jaring kubus dan balok ke dalam tulisan; (4) siswa masih kesulitan dalam menyelesaikan soal cerita yang berhubungan dengan kemampuan pemahaman konsep; (5) Siswa masih belum paham mengerjakan LAS; (6) Siswa masih belum melaksanakan kegiatan diskusi sesuai dengan tujuan pembelajaran kooperative tipe jigsaw sehingga suasana kelas ribut dan gaduh

\section{Rencana Tindakan}

Untuk mengatasi kesulitan-kesulitan siswa tersebut, tindakan yang akan dilakukan pada siklus II untuk meningkatkan pemahaman konsep adalah; (1) membuat model Balok dan kubus (alat peraga) dengan tujuan agar proses pembelajaran siswa menangkap gambar lebih terbantu; (2) membentuk kelompok diskusi yang terdiri dari 3 orang satu kelompok berdasarkan penyebaran kemampuan/tes siklus I; (3) mempersiapkan sarana pendukung pembelajaran yang mendukung pelaksanaan tindakan; (4) Mempersiapkan instrumen penelitian; (5) guru diharapkan lebih baik lagi dalam mengelola kondisi kelas terutama saat berdiskusi; (6) pemberian sanksi bagi kelompok yang tidak tertib; (7) melakukan perefleksian jawaban siswa mengingatkan kepada siswa untuk teliti atas jawaban yang meraka buat.

\section{Pelaksanaan Tindakan}

Pelaksanaan tindakan II terdiri dari dua pertemuan untuk melaksanakan kegiatan pembelajaran sesuai RPP yang telah disusun dan satu pertemuan untuk melakukan tes kemampuan pemahaman konsep siswa. Pelaksanaan tindakan II tersusun atas; (1) memberikan apersepsi kepada siswa dengan menyampaikan tujuan pembelajaran yang akan dicapai tiap pertemuan; (2) menyajikan informasi kepada siswa melalui Power Point, serta membuat media pembelajaran yang terbuat dari steroform untuk menjelaskan jenis-jenis diagonal dengan bantuan benang, model kubus dan balok yang terbuat dari kardus untuk menunjukkn jaring-jairng kubus dan balok untuk memperkuat tentang konsep luas permukaan kubus dan balok; (3) saling melempar jawaban antara anggota kelompok; (4) guru membimbing siswa memahami materi ajar melalui tanya jawab mengenai materi volume kubus dan balok; (4) guru memberikan contoh latihan soal cerita kemudian membimbing siswa menyelesaikannya.

\section{Pengamatan}

Berdasarkan hasil observasi siklus II, diperoleh kemampuan guru dalam mengelolah pembelajaran pada pertemuan I, diperoleh kemampuan guru dalam mengelolah pembelajaran pada pertemuan I sebesar 87,5\% dengan nilai rata-rata 3,50, sedangkan pada pertemuan II diperoleh kemampuan guru dalam mengelolah pembelajaran sebesar 92\% dengan nilai rata-rata 3,68. Dari hasil observasi tersebut, dapat dilihat bahwa pengelolahan pembelajaran oleh guru sudah tergolong kategori sangat baik. Pengelolahan pembelajaran semakin meningkat dari siklus I ke siklus II, ini dapat dilihat dari nilai yang diberikan observer yang semakin baik.

\section{Deskripsi Tes Kemampuan Pemahaman Konsep II}

Pada tes kemampuan pemahaman konsep dan kreativitas siswa tahap kedua ini diujikan kepada 40 siswa artinya seluruh siswa hadir. Berdasarkan hasil tes kemampuan Pemahaman konsep dan kreativitas untuk siklus II diperoleh bahwa kemampuan siswa baik pemahaman konsep maupun kreativitas siswa dalam menyelesaikan soal mengalami peningkatan. Hal ini dapat dilihat 
dari peningkatan rata-rata kemampuan antara siklus I dengan siklus II, rata-rata kemampuan pemahaman konsep meningkat dari 63,9 pada siklus I menjadi 75,5 pada siklus II artinya meningkat sebesar 18,1\% dari siklus I, sedangkan pada rata-rata kemampuan kreativitas siswa meningkat dari 69,5 pada siklus I menjadi 79,4 pada siklus II atau meningkat sebesar 14,2\% dari siklus I.

Berdasarkan pada hasil tahap kedua yaitu tes kemampuan pemahaman konsep diperoleh 9 siswa (26\%) berkategori sangat baik, 16 siswa (47\%) berkategori baik, 14 siswa (41\%) berkategori cukup baik, 1 siswa (3\%) berkategori kurang baik, dan 0 siswa ( $0 \%$ ) berkategori sangat kurang. Rata-rata kemampuan pemahaman konsep siswa adalah 75,5, hasil selengkapnya dapat dilihat pada garfik 1.

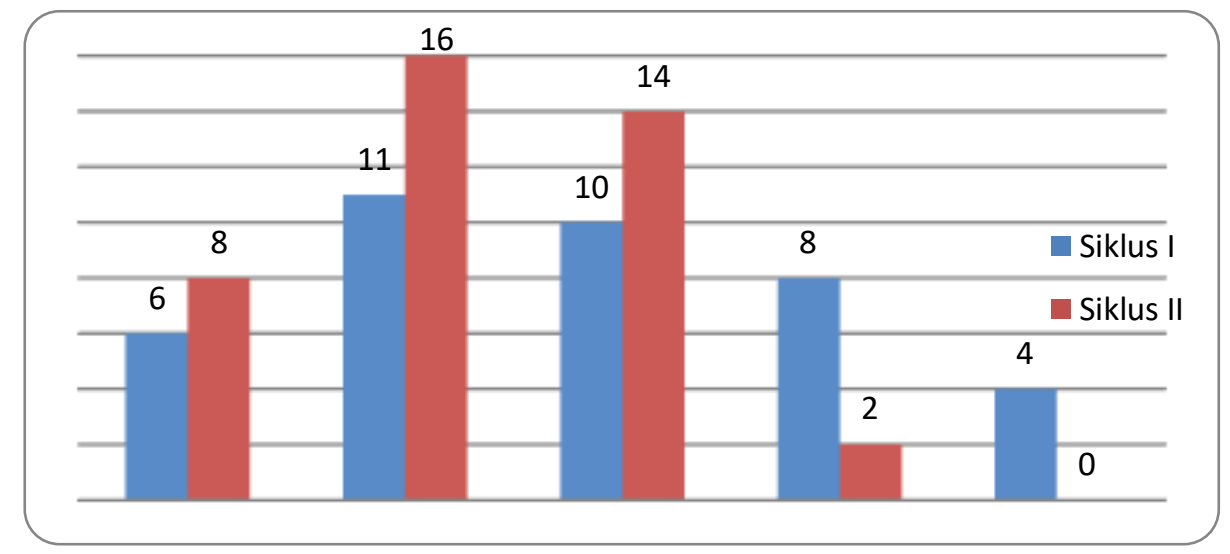

Garfik 1. Perbandingan hasil tes pemahaman konsep siswa Siklus I dan Siklus II

\section{KESIMPULAN}

Secara umum, pada bagian penutup penulis menguraikan jawaban atas masalah penelitian (pertanyaan penelitian) yang dikaji serta implikasi teoritis dari hasil/temuan penelitian tersebut. Penekanan perlu dilakukan pada temuan yang dipandang memiliki nilai kebaruan dari penelitian tersebut, misalnya kontribusi hasil penelitian ini terhadap teori yang terkait.

\section{DAFTAR PUSTAKA}

Abdurrahman. (2009). Pendidikan bagi anak berkesulitan belajar. Jakarta: PT Rineka Cipta

Arikunto, S. (2009). Dasar-dasar evaluasi pendidikan. Jakarta: Bumi Aksara.

Budiningsih, C. A. (2005). Belajar dan pembelajaran. Jakarta: Rineka Cipta

Depdikbud. (2003). Kamus besar bahasa Indonesia. Jakarta: Balai Pustaka

Hamalik, O. (2008). Proses belajar mengajar. Jakarta: Bumi Aksara.

Hudojo, H. (1988). Mengajar belajar matematika. Jakarta: Depdikbud.

Isjoni, H. (2009). Cooperative learning. Bandung: Alfabeta.

Lie, A. (2002). Cooperative learning. Jakarta: Grasindo.

Munandar, S.C.U. (1999). Pengembangan kereativitas anak berbakat. Jakarta: Rineka Cipta.

Nana, S. (2004). Dasar-dasar proses belajar mengajar. Jakarta: Bumi Aksara.

Riadi, A. (2011). Studi komparasi kemampuan penalaran dan pemahaman matematik siswa antara penerapan pendekaran open-ended dan ekspositori serta kaitannya dengan kemampuan awal siswa di SMA Negeri 2 Kejujuruan Awal Muda Aceh Tamiang. Tesis tidak diterbitkan. Medan: Universitas Negeri Medan.

Sagala. (2009). Konsep dan makna pembelajaran. Bandung: Alfabeta.

Sardiman, A. M. (2009). Interaksi dan motivasi belajar belajar mengajar. Jakarta: Rajawali Pers

Sinaga, B. (2007). Pengembangan model pembelajaran matematika berdasarkan masalab berbasis budaya batak

(PBM-B3). Disertasi tidak diterbitkan. Surabaya: Universitas Negeri Surabaya.

Slameto. (2010). Belajar dan faktor -faktor yang mempengarubi. Jakarta: Rineka Cipta.

Sudijono, A. (2009). Pengantar evaluasi pendidikan. Jakarta: PT Raja Grafindo Persada 
2020, 1(1)

Penerapan model pembelajaran kooperatif tipe jigsaw untuk meningkatkan kemampuan...

Suprijono. (2010). Cooperative learning teori dan aplikasi PAIKEM. Yogyakarta: Pustaka Pelajar

Tambunan, J. A. (2011). Penerapan model pembelajaran problem based learning untuk meningkatkan aktivitas dan hasil belajar siswa kelas X SMA RK Serdang Murni Lubuk Pakam Tabun Ajaran 2010/2011. Skripsi tidak diterbitkan. Medan: Uniersitas Negeri Medan.

Trianto. (2007). Model-model pembelajaran inovatif berorientasi konstruktivistik. Jakarta: Prestasi Pustaka.

Winkel, W. S. (1999). Psikologi pengajaran. Jakarta: Gramedia. 